ROCZNIKI TEOLOGICZNE

Tom LXVI, zeszyt 12 - 2019

DOI: http://dx.doi.org/10.18290/rt.2019.66.12-9

\author{
KS. ANDRZEJ TOMKO \\ TOMASZ CHŁOPECKI
}

\title{
AKTYWNOŚĆ BISKUPA STANISŁAWA ADAMSKIEGO W OKRESIE II RZECZYPOSPOLITEJ
}

\author{
THE ACTIVITY OF BISHOP STANISLAW ADAMSKI \\ IN THE PERIOD OF THE SECOND POLISH REPUBLIC
}

A b s t $\mathrm{r}$ a c t. The article The activity of Bishop Stanislaw Adamski in the period of the Second Polish Republic in a complex way presents the shaping of the concept by Bishop Adamski after Poland regained Independence. The complex issues of this period in Polish history prompted the authors to pay particular attention to the subject of the state, law, science, the role of the Catholic Church and the economy in the thought of Bishop Stanislaw Adamski - a figure with extraordinary talents - a priest, citizen, social worker, economist, and Senator.

Key words: Catholic Church; Second Polish Republic; science; law; economy; Catholic Action; state.

Ksiądz Stanisław Adamski urodził się dnia 12 kwietnia 1875 r. we wsi Zielonagóra. W 1896 r. wstąpił do Seminarium Duchownego w Poznaniu i po święceniach kapłańskich, w 1899 r., podjął działalność społeczną w Stowarzyszeniu Młodych Przemysłowców i w Stowarzyszeniu Polskich Robotników

Ks. dr hab. ANDRZEJ TOMKO, prof. PWT - pracownik naukowy Papieskiego Wydziału Teologicznego we Wrocławiu, dyrektor Instytutu Filozofii Chrześcijańskiej i Nauk Społecznych; adres do korespondencji: pl. Katedralny 9, 50-328 Wrocław; e-mail: atomko@pwt.wroc.pl; ORCID: 0000-0003-0209-5579.

Dr TOMASZ CHŁOPECKI - adiunkt na Wydziale Prawa i Administracji Wyższej Szkoły Prawa we Wrocławiu, ul. Św. Jadwigi 12, 50-266 Wrocław; e-mail: tchlopecki @gmail.com; ORCID: 0000-0002-3672-3230. 
Katolickich ${ }^{1}$. W 1904 r. po przeniesieniu do Poznania na stanowisko kanonika Kolegiaty, objął urząd generalnego sekretarza Związku Katolickich Towarzystw Robotników Polskich ${ }^{2}$ oraz redaktora „Robotnika”3. Adamski pracował także w Towarzystwie Pomocy Naukowej im. Karola Marcinkowskiego ${ }^{4}$ oraz Związku Spółdzielni ${ }^{5}$, gdzie prowadził redakcję „Poradnika Spółdzielni" ${ }^{\circ}$. Ważnym wydarzeniem w pracy dla dobra odrodzonej ojczyzny był wybór Adamskiego w 1919 r. na posła do Sejmu Ustawodawczego ${ }^{7}$ Odrodzonej Polski, a w latach 1922-1927 do Senatu Rzeczypospolitej. W 1928 r. Stanisław Adamski otrzymał misję organizacji Naczelnego Instytutu Akcji Katolickiej z siedzibą w Poznaniu ${ }^{8}$. Należał także do współorganizatorów Uniwersytetu Poznańskiego, którego został honorowym profesorem9. Papież Pius XI

\footnotetext{
${ }^{1}$ Por. K. Szaraniec, Ks. Stanistaw Adamski. W kręgu spotecznej działalności, cz. 1, Muzeum Śląskie, Katowice 1990, s. 3-4.

2 Por. S. ADAMSKI, Sposób zakładania towarzystw robotników katolickich, Drukarnia i Księgarnia św. Wojciecha, Poznań 1907, s. 3-22.

${ }^{3}$ Por. K. Szaraniec, Ks. Stanistaw Adamski. W Naczelnej Radzie Ludowej, cz. 2, Muzeum Śląskie, Katowice 1991, s. 3-5.

${ }^{4}$ Zob. S. ADAMSKI, Stowarzyszenia polskie wobec ustawy o stowarzyszeniach obowiazujacej od 15-go maja 1908. Praktyczne wskazówki dla zarzadów i przewodniczacych ze szczególnym uwzględnieniem sposobu zakładania nowych stowarzyszeń, Drukarnia i Księgarnia św. Wojciecha, Poznań 1909.

${ }^{5}$ Zob. S. ADAMSKI, Najbliższe zadania spótdzielczości zorganizowanej w Zwiazku Spótdzielni Zarobkowych i Gospodarczych. Przedmowa wstępna na Sejmiku Spótdzielni wygłoszona dnia 25 września 1923 r., Poznań 1924, s. 3-19; S. ADAMSKI, Unja Zwiazków Spółdzielczych w Polsce, Poznań b.r.w., s. 7-26; S. ADAMSKI, Ruch Spótdzielczy w Polsce oraz znaczenie i zadania Unji Zwiazków Spótdzielczych, Poznań b.r.w., s. 5-13.

${ }^{6}$ Por. K. Szaraniec, Ks. Stanistaw Adamski. W kręgu społecznej działalności, s. 4.

7 Zob. Sprawozdanie Stenograficzne z 45 posiedzenia Sejmu Ustawodawczego z dnia 4 czerwca 1919; Sprawozdanie Stenograficzne z 55 posiedzenia Sejmu Ustawodawczego z dnia 25 czerwca 1919; Sprawozdanie Stenograficzne z 83 posiedzenia Sejmu Ustawodawczego z dnia 1 sierpnia 1919; A. AJNENKIEL, Parlamentaryzm II Rzeczypospolitej, Wydawnictwo Wiedza Powszechna, Warszawa 1975; A. AJNENKIEL, Spór o model parlamentaryzmu polskiego do roku 1926, Wydawnictwo Książka i Wiedza, Warszawa 1972.

${ }^{8}$ Por. K. SZARANIEC, Ks. Stanisław Adamski. W kręgu społecznej działalności, s. 4.

${ }^{9}$ Zob. S. AdAmski, Reorganizacja bankowości w Polsce, Druk. Robotników Chrześcijańskich, Poznań 1926, s. 5-31; Zob. Pierwsze sprawozdanie Zwiazku Spótek Ślaskich za rok 1914. Zestawit i ogłosit Ks. St. Adamski Przewodniczacy Zwiazku, Nakł. Związku Spółek Zarobkowych, Poznań 1915, s. 3-6; S. ADAMSKI, Zasady pracy spótkowej. W świetle uchwat i doświadczeń zwiazku spółek zarobkowych i gospodarczych na w. x. poznańskie i Prusy zachodnie, część I materiały, Nakł. Związku Spółek Zarobkowych, Poznań 1918. Por. K. Szaraniec, Ks. Stanistaw Adamski. W kręgu spotecznej działalności, s. 4-5.
} 
powołał księdza Adamskiego na Biskupa ordynariusza diecezji katowickiej $^{10}$.

Biskup Stanisław Adamski zwracał uwagę, że oddziaływanie Episkopatu i ogólnopolskiej Akcji Katolickiej ${ }^{11}$, głoszących naukę Kościoła dotyczącą szkoły i wychowania, niewątpliwie głęboko oddziaływały na umysły społeczeństwa, doprowadzając tym samym do konsolidacji poglądów w dziedzinie szkolnej i do konkretnych osiągnięć, do których można było zaliczyć następujące tendencje: szkoła wyznaniowa dla młodzieży katolickiej stała się postulatem powszechnym katolików; zrozumienie konieczności powrotu do niezmiennych zasad moralności katolickiej oraz wprowadzenie wykładów zawodowej etyki katolickiej ${ }^{12}$. Biskup Adamski przedstawiał możliwość istnienia szkoły wspólnej, mieszanej dla dzieci różnych wyznań oraz szkoły wyznaniowej przeznaczonej dla dzieci tego samego wyznania $^{13}$. Ideałem szkoły katolickiej była szkoła wyznaniowa ${ }^{14}$, która opierała na następujących elementach: nie tylko wszyscy nauczyciele i uczniowie są katolikami; nie tylko nauka i praktyka religii nie napotyka na trudności i na przeciwdziałanie; nie tylko unika się w całym nauczaniu niezgodności z nauką i etyką katolicką, ale w której nauka, we wszystkich przedmiotach, pozostawała w pozytywnej zgodzie z nauką Kościoła katolickiego ${ }^{15}$.

\section{AKTYWNOŚĆ BISKUPA STANISŁAWA ADAMSKIEGO}

W liście pasterskim z dnia 12 lutego 1936 r. Biskup podkreślał, że religia w Polsce pełniła funkcję pierwszorzędną, bowiem była nie tylko zbiorem

\footnotetext{
${ }^{10}$ Zob. S. ADAMSKI, Misja wewnętrzna Diecezji Katowickiej, drukiem Księgarni i Drukarni Katolickiej, Katowice 1931, s. 5-21; S. ADAMSKI, List Pasterski. Stanistaw z powołania Stolicy Apostolskiej Biskup Katowicki przesyła swej drogiej Diecezji, Czcigodnym Braciom Kapłanom, wszystkim ukochanym wiernym pozdrowienie i błogostawieństwo Chrystusowe, Katowice 1936, s. 1-22; por. B. MiCHALSKI, Działalność spoteczno-polityczna księdza Stanistawa Adamskiego w latach 1899-1930, „Chrześcijanin w Świecie” 1977, nr 59-60, s. 18; zob. B. WoźNICA, Z historii diecezji katowickiej, „Chrześcijanin w Świecie” 1977, nr 59-60, s. 43; S. ADAMSKI, Szkoła wedle nauki Kościoła i Uchwat Synodu, Katowice 1939, s. 6.

${ }^{11}$ Por. S. ADAMSKI, W stużbie idei, Warszawa, b.r.w, s. 20-23.

12 Por. S. ADAMSKI, Szkoła wedle nauki Kościoła, s. 4-5.

${ }^{13}$ Por. S. AdAMSKI, Szkoła wyznaniowa czy mieszana?, Poznań b.r.w., s. 5-6; zob. Z. RzEPECKA, W stużbie dobra i prawdy, Nakładem Zjednoczenia Młodzieży Polskiej, Poznań 1931, s. $110-111$.

14 Por. S. ADAMSKI, Szkoła wyznaniowa, s. 27-39.

${ }^{15}$ Por. S. AdAMSKI, Szkoła wedle nauki Kościoła, s. 10; zob. S. ADAMSKI, Szkoła wyznaniowa, s. 7-9.
} 
wiadomości, ale przede wszystkim nauką życia; kształceniem silnej woli i stałego charakteru - słowem formowania pełnego człowieka, świadomego swoich obowiązków i zadań wobec Boga, rodziny i społeczeństwa ${ }^{16}$. Rzeczpospolita Polska układem ze Stolicą Apostolską zapewniła młodzieży naukę religii w szkole, a przez przedstawicieli rządu niejednokrotnie oświadczano, że pragnie, aby wychowanie młodzieży i nauczanie dzieci katolickich pozostawało w zgodzie ze wskazaniami religii katolickiej ${ }^{17}$. Ideałem szkoły dla młodzieży katolickiej nie była szkoła państwowa czy prywatna, ale zdecydowanie katolicka - wysoko zorganizowana pod względem funkcjonowania i nauczania, jednolita w całym państwie i przeniknięta duchem katolickim ${ }^{18}$.

Warto także podkreślić, że artykuł 93 Traktatu wersalskiego stanowił, że „Polska przyjmowała postanowienia, które główne mocarstwa sprzymierzone i stowarzyszone uznają za konieczne dla ochrony w Polsce interesów mieszkańców, różniących się od większości ludności rasą, językiem lub religią i godziła się na zamieszczenie tych postanowień w traktacie pomiędzy tymi mocarstwami". Zgodnie z tym artykułem Polska zawarła z głównymi mocarstwami sprzymierzonymi i stowarzyszonymi tzw. traktat o mniejszościach ${ }^{19}$, podpisany w Wersalu $\mathrm{z}$ tą samą datą, co Traktat wersalski ${ }^{20}$.

${ }^{16}$ Por. S. AdAMSKI, Misja wewnętrzna Diecezji Katowickiej, s. 5-21; S. ADAMSKI, List Pasterski. Stanistaw z powołania Stolicy Apostolskiej Biskup Katowicki przesyta swej drogiej Diecezji, s. 18.

${ }^{17}$ Por. L. ZIELENIEWSKI, Zagadnienie mniejszości narodowych w Konstytucji Rzeczypospolitej. Zarys historyczno-dogmatyczny, Warszawa 1935, s. 3.

18 Por. S. AdAmski, List Pasterski. Stanistaw z powotania Stolicy Apostolskiej Biskup Katowicki przesyła swej drogiej Diecezji, s. 20.

19 Traktat o ochronie mniejszości z 28 czerwca 1919 r. jako ustawa międzynarodowa został podpisany przez Polskę wraz z Traktatem Pokoju; zawierał jednostronne zobowiązania wobec mocarstw sprzymierzonych i stowarzyszonych. Artykuły zawarte w Traktacie regulowały kwestie związane z ochroną życia i wolności; tolerancją religijną. Dokument gwarantował możliwość używania własnego języka w życiu prywatnym i publicznym. Regulował kwestie związane ze szkolnictwem; z zakładami religijnymi, dobroczynnymi i społecznymi; udziałem mniejszości w podziale funduszy publicznych oraz uwzględniał prawa Żydów. Rząd polski traktował traktat jako prawa narzucone i ingerujące w suwerenność państwa i na XV Zgromadzeniu Ligi Narodów w 1934 r. zażądał zastąpienia tych norm prawami narodowymi oraz oświadczył, że wstrzymuje się od realizacji współpracy międzynarodowej w wykonywaniu postulatów wersalskich. Zob. F. BRZEZIŃSKI, Prawa mniejszości. Komentarz do Traktatu z dn. 28 czerwca 1919 r. pomiędzy Polska a Gtównymi Mocarstwami, Warszawa 1920; por. H. KISSINGER, Dyplomacja, Wydawnictwo Bellona, Warszawa 1996; S. MAUERSBERG, Szkolnictwo powszechne dla mniejszości narodowych w Polsce w latach 1918-1939, Zakład Narodowy im. Ossolińskich. Wydawnictwo Polskiej Akademii Nauk, Wrocław 1968; poglądy Biskupa na sprawy narodowościowe były przez niego przedstawione także po II wojnie światowej. Zob. 
Przechodząc do tematyki szkolnictwa wyższego, Biskup Adamski zwracał uwagę, że Polska posiadała następujące katolickie instytucje o charakterze wyższych szkół: Wyższe seminaria duchowne we wszystkich diecezjach; fakultety teologiczne przy czterech uniwersytetach; Katolicki Uniwersytet w Lublinie z wydziałami: teologicznym, prawa kościelnego, prawa świeckiego i nauk społeczno-ekonomicznych, nauk humanistycznych oraz wydziałem pedagogicznym. Wychowanie katolickiego duchowieństwa na poziomie uniwersyteckim było zatem zapewnione przez dobrze funkcjonujące i liczne seminaria duchowne, a fakultety teologiczne przy uniwersytetach rozwijały się dobrze i prowadziły niezmiernie pożyteczną działalność $\mathrm{w}$ dziedzinie wychowania duchowieństwa ${ }^{21}$.

Chcąc ocenić prawną stronę stosunku szkoły polskiej do nauczania religii katolickiej należy wrócić do aktu, który dla prawnego stanowiska polskiej szkoły miał zasadnicze znaczenie - konkordatu zawartego dnia 10 lutego 1925 r. $^{22}$ między Stolicą Apostolską a Rzeczypospolitą Polską. Artykuł XIII opierał się na odpowiednich artykułach konstytucji polskiej i nie był tylko prawem kościelnym, ale i państwową ustawą, zatwierdzoną przez władze ustawodawcze specjalnym aktem prawnym ${ }^{23}$. Artykuł ten stanowił, że we wszystkich szkołach publicznych, z wyjątkiem szkół wyższych, nauka religii jest obowiązkowa. Nauka ta miała być udzielana młodzieży katolickiej przez nauczycieli, mianowanych przez władze szkolne, które ich wybierały wyłącznie spośród osób upoważnionych przez Ordynariuszy do nauczania religii; takie same zasady dotyczące wyboru i odwołania nauczycieli nauczających

S. ADAMSKI, Poglad na rozwój sprawy narodowościowej w wojew. ślaskim w czasie okupacji niemieckiej, nakładem Księgarni św. Jacka, Katowice 1946, s. 7-23.

20 Por. A. PeretiatKowicz, Wiadomości prawno-polityczne, w: Polska wspótczesna. Geografia polityczna Polski. Kultura duchowa. Wiadomości prawno-polityczne, red. J. Bystroń, S. Pawłowski, A. Peretitkowicz, Lwów-Warszawa 1936, s. 230.

${ }^{21}$ Por. S. ADAMSKI, Szkoła wedle nauki Kościoła, s. 14-15.

22 Dz.U. Nr 72, poz. 501; Konkordaty są umowami w znaczeniu układów międzynarodowych i obowiązują Kościół i państwo do chwili bądź wypowiedzenia, bądź zawarcia nowego konkordatu. Konkordat zawarty pomiędzy Stolicą Apostolską i Rzeczypospolitą Polską podpisany w dniu 10 lutego 1925 r., zatwierdzony przez ustawę z dnia 23 kwietnia 1925 r. i ratyfikowany przez wymianę dokumentów w dniu 2 czerwca 1925 r., wszedł w życie z dniem 3 sierpnia 1925 r.; równocześnie na mocy art. XXV Konkordatu utraciły na ziemiach polskich moc obowiązującą sprzeczne z postanowieniami Konkordatu ustawy, rozporządzenia i dekrety, wydane przez Rosję, Austrię i Prusy. Zob. S. ŁUKOMSKI, Konkordat zawarty dnia 10 lutego 1925 roku pomiędzy Stolica Apostolska i Rzeczpospolita Polska, Księgarnia „Unitas”, Łomża 1934, publikacja nienumerowana.

${ }^{23}$ Por. S. ADAMSKI, Szkoła wedle nauki Kościoła, s. 22. 
miały być stosowane do profesorów, docentów i asystentów uniwersyteckich na wydziałach teologii katolickich uniwersytetów państwowych ${ }^{24}$. Biskup Adamski zwracał uwagę na szczególny stosunek duchowieństwa do nauczycielstwa, zwłaszcza szkół powszechnych - wszyscy nauczyciele, zwłaszcza w okresie, w którym Kościół i Państwo polskie zgodzili się na to, aby szkoła miała na celu najwyższe religijne i moralne wychowanie młodzieży, przy udziale nie tylko państwa, ale także rodziców i Kościoła ${ }^{25}$.

Należy podkreślić, że w związku z art. XIII Konkordatu zostały uchwalone następujące rozporządzenia: Rozporządzenie Ministra Wyznań Religijnych i Oświecenia Publicznego z dnia 9 grudnia 1926 r. o nauce szkolnej religii katolickiej ${ }^{26}$; Okólnik Ministerstwa Wyznań Religijnych i Oświecenia Publicznego w sprawie postępowania władz szkolnych przy mianowaniu nauczycieli religii katolickiej z dnia 24 kwietnia 1926 r., nr 0. prez. 3284/26 ${ }^{27}$; Rozporządzenie Ministra Wyznań Religijnych i Oświecenia Publicznego z dnia 10 grudnia 1925 r. w sprawie kwalifikacji zawodowych duchownych rzymskokatolickich do nauczania religii w szkołach średnich ogólnokształcących i seminariach nauczycielskich państwowych i prywatnych ${ }^{28}$; Rozporządzenie Ministra Wyznań Religijnych i Oświecenia Publicznego z dnia 27 grudnia 1926 r., nr 6767/26 w sprawie kwalifikacji zawodowych duchownych rzymsko-katolickich ${ }^{29}$; Rozporządzenie Ministra Wyznań Religijnych i Oświecenia Publicznego z dnia 30 maja 1932 r. w sprawie wykonania niektórych postanowień rozporządzenia Prezydenta Rzeczypospolitej z dnia 6 marca 1928 r. o kwalifikacjach zawodowych nauczycieli szkół powszechnych ${ }^{30}$; Okólnik Ministerstwa Wyznań Religijnych i Oświecenia Publicznego z dnia 13 grudnia 1926 r., Nr I 18458/26 w sprawie misji kanonicznej duszpasterzy; Rozporządzenie Prezydenta Rzeczypospolitej z dnia 21 października 1932 r. w sprawie zmiany ustawy z dnia 1 lipca 1926 r. o stosunkach służbowych nauczycieli w ujęciu Obwieszczenia Ministra Wyznań Religijnych i Oświecenia Publicznego z dnia 9 listopada 1932 r. $^{31}$; Okólnik Nr 18 z dnia 11 lipca 1932 r. (II S-5361/32) w sprawie przenoszenia lub zwalniania księży

\footnotetext{
${ }^{24}$ Por. S. ŁUKOMSKI, Konkordat zawarty dnia 10 lutego 1925, s. 103-104.

25 Por. S. AdAMSKI, Z zagadnień i trudności duszpasterskich Diecezji Ślaskiej, Nakł. Księgarnia Katolicka Sp. Akcyjna, Katowice 1938, s. 13.

${ }^{26}$ Dz.U. Nr 1, poz. 9.

${ }^{27}$ Dz. Urzędowy Min. W.R. i O.P., nr 9, poz. 104.

${ }^{28}$ Dz.U. Nr 131, poz. 938.

${ }^{29}$ Dz. Urzędowy Min. W.R. i O.P., nr 2, poz. 27.

${ }^{30}$ Dz.U. Nr 51, poz. 487.

${ }^{31}$ Dz.U. Nr 104, poz. 873.
} 
prefektów szkół średnich ogólnokształcących i zakładów kształcenia nauczycieli; Rozporządzenie Ministra Wyznań Religijnych i Oświecenia Publicznego z dnia 1 marca $1926 \mathrm{r}$. w sprawie wynagrodzenia duszpasterzy udzielających nauki religii w szkołach powszechnych ${ }^{32}$; oraz Rozporządzenie Ministra Wyznań Religijnych i Oświecenia Publicznego z dnia 3 maja 1926 r., L. O. Prez. 3282/26 w sprawie egzaminu dojrzałości w seminariach duchownych ${ }^{33}$.

Biskup Stanisław Adamski zwracał także uwagę, że Konkordat był prawem zatwierdzonym przez Sejm i Senat, podpisanym przez Prezydenta Rzeczypospolitej i obowiązywał zatem nie tylko jako prawo Kościoła, lecz także jako prawo polskie - art. I stanowił, że Kościół katolicki, bez różnicy obrządków, korzystać będzie w Rzeczypospolitej Polskiej z pełnej wolności. Państwo zapewnia Kościołowi swobodne wykonywanie Jego władzy duchownej i Jego jurysdykcji, jak również swobodną administrację i zarząd Jego sprawami i Jego majątkiem zgodnie z Prawami Boskimi i Prawem Kanonicznym ${ }^{34}$. Biskup zwracał uwagę także, że zgodnie z art. 174 kodeksu karnego (kk): „Kto złośliwie przeszkadza publicznemu zbiorowemu wykonywaniu aktu religijnego uznanego prawnie wyznania lub związku religijnego, podlega karze aresztu do lat 2" - Juliusz Makarewicz, jeden z najwybitniejszych polskich znawców prawa karnego w komentarzu do art. 174 kk stwierdził: „przestępstwo to polega na przeszkadzaniu aktowi religijnemu, a więc nie tylko aktowi kultu, może to być przeszkadzanie pogrzebowi (możliwość zbiegu ustawy art. 168 i 174), o ile ma charakter religijny ze względu na udział duchowieństwa lub inne oznaki, może to być przeszkadzanie wspólnym modlitwom, procesji itp. Akt religijny musi być publiczny, zbiorowy, a więc nie wystarczy modlitwa jednostki przed krzyżem wystawionym na miejscu publicznym, odwrotnie nie wystarczy zbiorowa modlitwa w domu prywatnym, akt religijny musi być publiczny i zbiorowy" ${ }^{\prime 3}$.

\footnotetext{
${ }^{32}$ Dz.U. Nr 27, poz. 163.

${ }^{33}$ Por. S. ŁUKOMSKI, Konkordat zawarty dnia 10 lutego 1925, s. 106-124.

${ }^{34}$ Tamże, s. 48. Zapewnienie Kościołowi katolickiemu pełnej wolności obejmowało zatem: wszystkie obrządki Kościoła katolickiego; swobodne wykonywanie wszelkich jego spraw wchodzących w zakres władzy duchownej i władzy majątkowo-administracyjnej; uznanie prawa boskiego i prawa kanonicznego jako normy działania Kościoła; Państwo zatem nie mogło Kościoła w sprawach duchownych krępować lub mu przeszkadzać, owszem powinno czuwać nad tym, aby Kościół mógł swobodnie swoją władzę wykonywać; co do zarządu majątkiem kościelnym, Kościół podlegał tylko tym ograniczeniom, które wynikały wprost z zapisów w Konkordacie.

${ }^{35}$ Por. Okólnik J. E. Biskupa Stanisława Adamskiego do zarzadów, oddziałów i członków Akcji Katolickiej oraz Misji Wewnętrznej diec. katowickiej i Ślaska Zaolziańskiego, Katowice 1939, s. 9.
} 
Biskup Stanisław Adamski wskazywał na trzy wielkie działy obejmujące pracę Kościoła: primo - pracę kapłańską, uświęcenie dusz przez ofiarę Mszy św. i administrację Sakramentów św., do której Kościół Biskupów i kapłanów upoważnia przez święcenia; secundo - rządy w Kościele i jego częściach składowych, diecezjach, parafiach; tertio - głoszenie nauki Chrystusowej, nauczanie, apostołowanie, nawracanie, zdobywanie dusz, krzewienie i głoszenie prawd i praw Chrystusowych; „Akcja Katolicka była więc zorganizowaną pomocą świeckich w tym - trzecim dziale pracy Kościoła - udzielanie pomocy i współpracy Biskupom i kapłanom w apostolstwie, nauczaniu, nawracaniu, zdobywaniu dusz, krzewieniu i głoszeniu prawd i praw Chrystusowych - oto dziedziny, do której Bóg i Kościół powołuje każdego Katolika w Akcji Katolickiej”" ${ }^{\text {"3 }}$. Akcja Katolicka była zatem miejscem wspólnej pracy wszystkich katolików, bez względu na ich przynależność polityczną - tutaj wszyscy katolicy mieli uczyć się pielęgnowania obowiązujących powszechnie prawd i praw Chrystusowych, aby wnosić je i stosować w życiu i wszelkiej pracy prywatnej i zbiorowej ${ }^{37}$. W praktycznej pracy Akcji Katolickiej, zarówno zarządy stowarzyszeń, kierownictwa oddziałów, jak i członkowie powinni koncentrować swoją myśl na głównym przedmiocie Akcji - na apostolstwie, które z jednej strony każdy powinien wykonywać indywidualnie i osobiście, z drugiej strony zbiorowo przez swój oddział, współpracę z innymi oddziałami, stowarzyszeniami i zwiazzkami według programu wskazanego przez Episkopat i Biskupa diecezjalnego ${ }^{38}$. Także Papież Pius XI stale powracał do idei Akcji Katolickiej, począwszy od pierwszej encykliki Ubi arcano Dei, z dnia 23 grudnia 1922 r., w której wypowiedział następujące słowa: „chociażby praca ta (w Akcji Katolickiej) wydawała się trudna, połączona z mozołem dla pasterzy i wiernych, to jednak bez wątpienia jest ona potrzebna i należy do głównych obowiązków urzędu pasterskiego jak i życia chrześcijańskiego"39.

W liście pasterskim Biskupa Katowickiego na Wielki Post w 1935 r., Biskup Adamski odnosił się także do sytuacji społeczno-gospodarczej podkreślając, że chrześcijaństwo głosiło, iż: „Praca z Boga jest. Praca jest nie-

\footnotetext{
${ }^{36}$ Por. S. ADAMSKI, List pasterski Stanistawa Adamskiego Biskupa Katowickiego o Akcji Katolickiej, Katowice 1934, s. 6; zob. S. ADAMSKI, Akcja Katolicka młodzieży, Poznań 1936, 3-18; S. ADAMSKI, Zadania Akcji Katolickiej młodzieży, Poznań 1938, s. 12-23; 25-27; S. ADAMSKI, Parafialna Akcja Katolicka, nr 82, Poznań 1938.

37 Por. S. AdAMSKI, List pasterski Stanistawa Adamskiego Biskupa, s. 7.

38 Por. S. Adamski, Podstawy Pracy Stowarzyszeń Akcji Katolickiej, Książnica Akcji Katolickiej, nr 24, Poznań 1937, s. 49-51.

${ }^{39}$ Por. S. Bross, Pius XI o Akcji Katolickiej. List J. Św. Papieża Piusa XI „Laetus sane nuntius", do J.EM. Ks. Kard. Segura Y Saenz, Prymasa Hiszpanji z dn. 6. XI. 1929 r., Księgarnia św. Wojciecha, Poznań-Warszawa-Wilno-Lublin 1930, s. 2-3.
} 
odłączna od istoty człowieka, bo on jest obrazem Boga. Praca jest naśladownictwem Boga, który ciągle jest czynny - Ojciec mój działa aż do tej chwili (J 5,17) mówił Syn Boży"40. W kwestiach gospodarczych Biskup Adamski wielokrotnie zabierał także głos w Sejmie i Senacie - podczas dyskusji w Senacie nad prowizorium budżetowym i ustawami sanacyjnymi, dnia 22 grudnia 1925 r. zwracał uwagę na nadmierną rozbudowę aparatu państwowego i „,rozdęcie" do niewłaściwych rozmiarów maszyny państwowej, co wymagało pobierania nadmiernych podatków; zwracał także szczególną uwagę na trzy dziedziny wymagające naprawy: budżet, waluta, produkcja ${ }^{41}$.

W przemówieniu Biskupa Stanisława Adamskiego, wygłoszonemu na zlocie Katolickiego Stowarzyszenia Mężów diecezji katowickiej w Katowicach w dniu 12 sierpnia 1934 r., Biskup zwracał uwagę, że państwo nie posiada tych głębokich źródeł świętości, zwartości i siły, które mają Kościół i rodzina z woli Chrystusa ze względu na swoje zadania - państwo dobrze kierowane i rządzone mogło Kościołowi i obywatelom swoim niezmiennie ułatwić drogę do wiecznego celu; państwo źle zarządzane mogło tę drogę utrudniać ${ }^{42}$. Biskup Adamski podkreślał, że zarówno państwo, jak i władza istnieją z Bożej woli; prawa i obowiązki, które państwo nakładało na obywateli, nie obowiązywały tylko dlatego, że państwo mogło zmusić do uległości, lecz przede wszystkim na mocy prawa Bożego $^{43}$. Potęga państwa mogła ugruntować, rozwinąć, wzbogacić tylko wysoko wykształcony w poczuciu swoich obowiązków naród - dlatego kiedy wychowanie obywatelskie obowiązywało wszystkich obywateli, czyli mieszkańców

\footnotetext{
${ }^{40}$ Por. S. AdAMSKI, List Pasterski Biskupa Katowickiego na Wielki Post roku 1935 r., Katowice 1935, s. 10.

${ }^{41}$ Por. S. ADAMSKI, Drogi uzdrowienia gospodarczego Polski. Przemowa wypowiedziana $w$ Senacie podczas dyskusji nad prowizorium budżetowym $i$ ustawami sanacyjnymi, dnia 22 grudnia 1925 r., Poznań 1926, s. 1-3; Ksiądz Adamski zajmował się także - szczególnie w początkowym okresie swojej działalności naukowej - kwestiami dotyczącymi finansów i ubezpieczeń społecznych. S. ADAMSKI, Kasy oszczędnościowe w obrębie towarzystw, Poznań 1904; Por. S. ADAMSKI, Dlaczego mężatka nie powinna po ślubie żadać zwrotu sktadek z zabezpieczenia na niemoc i starość, Poznań 1905.

42 Por. S. ADAMSKI, Nasz stosunek do państwa. Przyczynki do programu katolickiego na Ślasku, Wyd. Nakładem Katolickiego Stowarzyszenia Mężów Diecezji Katowickiej, Katowice 1934, s. 25-26.

${ }^{43}$ Por. S. ADAMSKI, Nasz stosunek do państwa, s. 27. Należy także przytoczyć słowa Chrystusa, który stwierdził: „Oddajcie tedy, co jest cesarskiego, cesarzowi, a co jest Bożego, Bogu” (Mt 22,21) oraz św. Pawła „Każdy niechaj będzie poddany władzom wyższym, bo nie masz władzy jeno od Boga, a które są, od Boga są postanowione. Przeto kto się sprzeciwia władzy, sprzeciwia się postanowieniu Bożemu [...] Przetoż z obowiązku bądźcie poddani; nie tylko dla kary, ale też w sumieniu" (Rz 13,1-2,5).
} 
danego państwa, każde pokolenie narodu, którego formą organizacyjną było dane państwo, powinno otrzymać jeszcze wychowanie narodowe - zwracano także uwagę, że zaprzeczeniem patriotyzmu był egoizm, który był postawieniem na miejscu wielkiego dobra - całego narodu - jednostki, zastąpienie wielkich celów drobnymi, więcej często sprzecznymi z dobrem ogółu ${ }^{44}$.

Sprawy Kościoła katolickiego i innych wyznań religijnych wymagały także, żeby w Polsce istniało silne stronnictwo, które jawnie i otwarcie popierałoby zasady Kościoła katolickiego oraz broniło i reprezentowało interesy i prawa katolicyzmu w: dziedzinie tworzącego się dopiero ustawodawstwa; dziedzinie przyjęcia i wykonania konkordatu; kwestiach szkoły wyznaniowej i wychowania publicznego wraz z ustawami, które miały regulować szkolnictwo, stosunek do religii i prawa Kościoła do szkoły; w tworzeniu prawa rodzinnego, małżeńskiego; kierunku przyzwyczajania urzędów i urzędników do właściwego uznawania i rozumienia konstytucji i sprawiedliwości wobec wszystkich oraz życzliwości w odnoszeniu się do Kościoła i jego zarządzeń; wychowaniu ludności według jasnych i wyraźnych zasad opartych na chrześcijańskiej moralności ${ }^{45}$. Wskazywał także, że o ile chodziło o zabiegi polityczne, społeczno-reformatorskie, kulturalno-oświatowe, musiały łączyć się niezależne polityczne stronnictwa katolickie, ku wspólnej systematycznej i planowej akcji opartej na wspólnym porozumieniu, uświadomieniu sobie sił i środków ${ }^{46}$. Ruch katolicko-społeczny zarówno oświatowy, jak gospodarczy i polityczny wszystkich państw na całym świecie powinien pracować w celu wspólnego planu, nie zatracając tym samym ani organizacyjnej, ani narodowej odrębności i samodzielności ${ }^{47}$. Mówiąc o podstawach chrześcijańskiego stronnictwa politycznego, Biskup Adamski zwracał uwagę, że Chrześcijańskie Narodowe Stronnictwo Pracy ${ }^{48}$ należało do tych stronnictw, które opierało się na wierze w Boga w nieśmiertelną duszę oraz obowiązek podporządkowania życia ludzkiego przykazaniom Bożym i celowi wiecznemu ${ }^{49}$. Podstawo-

\footnotetext{
${ }^{44}$ Por. M. ŚLIWIŃSKA-ZARZECKA, Wychowanie spoteczne i obywatelskie, odbitka z „Oświaty Polskiej" (nr IV, V 1938 r.), Warszawa 1938, s. 20-21.

${ }^{45}$ Por. S. AdAmski, Zadania Chrześcijańskiej Demokracji w Polsce, nr 12, Poznań 1922, s. $10-11$.

46 Tamże, s. 11.

47 Tamże, s. 21.

${ }^{48}$ Zob. B. KRZYwobŁOCKA, Chadecja 1918-1937, Wydawnictwo PWN, Warszawa 1974; H. PRZYBYLSKI, Chrześcijańska Demokracja i Narodowa Partia Robotnicza $w$ latach 19261937, Wydawnictwo PWN, Warszawa 1980.

${ }^{49}$ Por. S. AdAMSKI, Zasady i dażenia Chrześcijańskiego Narodowego Stronnictwa Pracy, nr 2, Poznań 1921, s. 7.
} 
wymi zasadami, na których opierało swoje działanie stronnictwo, to: miłość, wolność i sprawiedliwość - urzeczywistnianie tych zasad w życiu społecznym, gospodarczym i państwowym było naczelnym zadaniem wszystkich członków stronnictwa $^{50}$. W myśl zasad stronnictwa i zapatrywań na doniosłość sprawy religijnej w państwie i w życiu człowieka, stronnictwo postulowało, aby wychowanie dzieci opierało się całlkowicie na fundamentach zasad Kościoła; nie uznawało szkoły świeckiej, która wykluczała naukę religii ${ }^{51}$. Zgodnie z zasadami programowymi Chrześcijańskie Narodowe Stronnictwo Pracy dążyło do tego, żeby Polska w polityce zagranicznej kierowała się szczerością, uczciwością i umiłowaniem pokoju; w stosunku do innych państw Polska była państwem samodzielnym i niezależnym, wskazując równocześnie na zagrożenia płynące zarówno od wschodnich, jak i zachodnich sąsiadów $^{52}$. W polityce wewnętrznej stronnictwo popierało rząd, usilnie domagając się, aby obóz rządzący nie nadużywał swojego stanowiska do partyjnych celów - opowiadano się za silnym rządem i twardą politykąa ${ }^{53}$.

Podsumowując, autorzy pragną podkreślić, że Biskup Stanisław Adamski był niekwestionowanym autorytetem w zakresie koncepcji państwa, roli Kościoła katolickiego w jakże trudnych czasach wojen światowych i okresu komunizmu, ale także w zakresie szkolnictwa i nauki, spółdzielczości, bankowości, ekonomii i gospodarki. Jego koncepcje z całą pewnością wykraczały poza czasy, w których przyszło mu żyć i nauczać. Całą prawdę o Biskupie i jego życiu zawarł Prymas Polski Kardynał Stefan Wyszyński, który w mowie pogrzebowej, wygłoszonej podczas uroczystości pogrzebowych w listopa-

\footnotetext{
50 Tamże, s. 9.

${ }^{51}$ Tamże, s. 24-26; w Rezolucji uchwalonej na zjeździe delegatów województwa poznańskiego w dniu 3 kwietnia 1921 r. zaznaczono m.in.: Zjazd delegatów kół województwa poznańskiego Chrześcijańskiego Narodowego Stronnictwa Pracy stwierdza, że jedno z najważniejszych żądań - szkoła wyznaniowa, nie doznała w konstytucji [konstytucja z 1921 r. - autorzy] dostatecznego uwzględnienia; wskutek przeciwnego szkole wyznaniowej stanowiska posłów Polskiego Stronnictwa Ludowego, Narodowej Partii Robotniczej, Socjalistów, Wyzwolenia, a przede wszystkim wskutek cofnięcia się przy głosowaniu w tej sprawie znacznej liczby głosów stronnictw prawicowych, zagwarantowana została konstytucyjnie jedynie szkoła symultana $\mathrm{z}$ obowiązkiem nauki religii.

52 Por. S. AdAMsKI, Zasady i dażenia, s. 34-35.

53 Tamże, s. 35-37.
} 
dzie 1967 r., scharakteryzował zmarłego Biskupa jako kapłana, obywatela, społecznika $^{54}$ i ekonomistę, a także posła i senatora ${ }^{55}$ - człowieka z głową ministra gospodarki narodowej, obdarzonego niezwykłymi talentami ${ }^{56}$ : „Człowieka o wielkiej kulturze i inteligencji, który musiał wszystko powiązać sprawiedliwie i słusznie, aby stało się przedziwną jednością"

\section{BIBLIOGRAFIA}

ADAMSKI S., Akcja Katolicka a duchowieństwo. Referat wypowiedziany na Kongregacji XX. Dziekanów w Poznaniu, w kwietniu 1929 r., Poznań-Warszawa-Wilno-Lublin 1929. ADAMSKI S., Akcja Katolicka młodzieży, Poznań 1936.

ADAMSKI S., Dlaczego mężatka nie powinna po ślubie żądać zwrotu składek z zabezpieczenia na niemoc i starość, Poznań 1905.

ADAMSKI S., Dlaczego duchowieństwo zajmuje się pracą społeczną, nr 11, Poznań 1921.

ADAMSKI S., Drogi uzdrowienia gospodarczego Polski. Przemowa wypowiedziana w Senacie podczas dyskusji nad prowizorium budżetowym i ustawami sanacyjnymi, dnia 22 grudnia 1925 r., Poznań 1926.

ADAMSKI S., Kasy oszczędnościowe w obrębie towarzystw, Poznań 1904.

ADAMSKI S., List Pasterski Biskupa Katowickiego na Wielki Post roku 1935 r., Katowice 1935. ADAMSKI S., List pasterski Stanisława Adamskiego Biskupa Katowickiego o Akcji Katolickiej, Katowice 1934.

ADAMSKI S., List Pasterski. Stanisław z powołania Stolicy Apostolskiej Biskup Katowicki przesyła swej drogiej Diecezji, Czcigodnym Braciom Kapłanom, wszystkim ukochanym wiernym pozdrowienie i błogosławieństwo Chrystusowe, Katowice 1936.

ADAMSKI S., Misja wewnętrzna Diecezji Katowickiej, drukiem Księgarni i Drukarni Katolickiej, Katowice 1931.

ADAMSKI S., Najbliższe zadania spółdzielczości zorganizowanej w Związku Spółdzielni Zarobkowych i Gospodarczych. Przedmowa wstępna na Sejmiku Spółdzielni wygłoszona dnia 25 września 1923 r., Poznań 1924.

ADAMSKI S., Nasz stosunek do państwa. Przyczynki do programu katolickiego na Śląski, Wyd. Nakładem Katolickiego Stowarzyszenia Mężów Diecezji Katowickiej, Katowice 1934.

AdAMski S., Parafialna Akcja Katolicka, nr 82, Poznań 1938.

ADAMSKI S., Podstawy Pracy Stowarzyszeń Akcji Katolickiej, Książnica Akcji Katolickiej, Nr 24, Poznań 1937.

\footnotetext{
${ }^{54}$ Zob. S. ADAMSKI, Dlaczego duchowieństwo zajmuje się praca społeczna, Nr 11, Poznań 1921, s. 5-18. Biskup Adamski pisał, że duchowieństwo ma prawo i obowiązek zajmowania się pracą społeczną: „Pierwszym powodem jest to, że pracą społeczną można przyjść z pomocą ludziom biednym i uciśnionym".

${ }^{55}$ Por. K. Szaraniec, Ks. Stanistaw Adamski. W Sejmie i Senacie, cz. 3, Muzeum Śląskie, Katowice 1991, s. 3-5.

56 Por. S. WYSZYŃSKI, Nad mogiła Biskupa - Męza Stanu, „Chrześcijanin w Świecie” 1977, nr 59-60, s. 38.

57 Tamże.
} 
ADAMSKI S., Pogląd na rozwój sprawy narodowościowej w wojew. śląskim w czasie okupacji niemieckiej, nakładem Księgarni św. Jacka, Katowice 1946.

ADAmski S., Reorganizacja bankowości w Polsce, Druk. Robotników Chrześcijańskich, Poznań 1926.

ADAMSKI S., Ruch Spółdzielczy w Polsce oraz znaczenie i zdania Unji Związków Spółdzielczych, Poznań b.r.w.

ADAMSKI S., Sposób zakładania towarzystw robotników katolickich, Drukarnia i Księgarnia św. Wojciecha, Poznań 1907.

ADAMSKI S., Stowarzyszenia polskie wobec ustawy o stowarzyszeniach obowiązującej od 15-go maja 1908. Praktyczne wskazówki dla zarządów i przewodniczących ze szczególnym uwzględnieniem sposobu zakładania nowych stowarzyszeń, Drukarnia i Księgarnia św. Wojciecha, Poznań 1909.

ADAMSKI S., Szkoła wedle nauki Kościoła i Uchwał Synodu, Katowice 1939.

ADAMSKi S., Szkoła wyznaniowa czy mieszana?, Poznań b.r.w.

ADAMSKi S., Unja Związków Spółdzielczych w Polsce, Poznań b.r.w.

ADAMSKI S., W służbie idei, Warszawa, b.r.w.

ADAMSKI S., Z zagadnień i trudności duszpasterskich Diecezji Śląskiej, Nakł. Księgarnia Katolicka Sp. Akcyjna, Katowice 1938.

ADAMSKi S., Zadania Akcji Katolickiej młodzieży, Poznań 1938.

ADAmski S., Zadania Chrześcijańskiej Demokracji w Polsce, nr 12, Poznań 1922.

ADAMski S., Zasady i dążenia Chrześcijańskiego Narodowego Stronnictwa Pracy, nr 2, Poznań 1921.

ADAMSKI S., Zasady pracy spółkowej. W świetle uchwał i doświadczeń związku spółek zarobkowych i gospodarczych na w. x. poznańskie i Prusy zachodnie, część I materiały, Nakł. Związku Spółek Zarobkowych, Poznań 1918.

ADAmsKi S., List Pasterski. Stanisław z powołania Stolicy Apostolskiej Biskup Katowicki przesyła swej drogiej Diecezji, Czcigodnym Braciom Kapłanom, wszystkim ukochanym wiernym pozdrowienie i błogosławieństwo Chrystusowe, Katowice 1936.

AJNENKIEL A., Parlamentaryzm II Rzeczypospolitej, Wydawnictwo Wiedza Powszechna, Warszawa 1975.

AJNENKIEL A., Spór o model parlamentaryzmu polskiego do roku 1926, Wydawnictwo Książka i Wiedza, Warszawa 1972.

Bross S., Akcja Katolicka według orzeczeń Stolicy Apostolskiej, Poznań 1929.

Bross S., Pius XI o Akcji Katolickiej. List J. Św. Papieża Piusa XI „Laetus sane nuntius”, do J. EM. Ks. Kard. Segura Y Saenz, Prymasa Hiszpanji z dn. 6. XI. 1929 r., Księgarnia św. Wojciecha, Poznań-Warszawa-Wilno-Lublin 1930.

BRZEZIŃSKI F., Prawa mniejszości. Komentarz do Traktatu z dn. 28 czerwca 1919 r. pomiędzy Polską a Głównymi Mocarstwami, Warszawa 1920.

KISSINGER H., Dyplomacja, Wydawnictwo Bellona, Warszawa 1996.

KrZYwobŁocKA B., Chadecja 1918-1937, Wydawnictwo PWN, Warszawa 1974.

List Ojca św. Piusa XI do Przewodniczącej Międzynarodowej Unii Kobiet Katolickich.

ŁUKOMSKI S., Konkordat zawarty dnia 10 lutego 1925 roku pomiędzy Stolicą Apostolską i Rzeczpospolitą Polską, Księgarnia „Unitas”, Łomża 1934.

MAUERSBERG S., Szkolnictwo powszechne dla mniejszości narodowych w Polsce w latach 1918-1939, Zakład Narodowy im. Ossolińskich. Wydawnictwo Polskiej Akademii Nauk, Wrocław 1968.

MiCHALSKi B., Działalność społeczno-polityczna księdza Stanisława Adamskiego w latach 1899-1930, „Chrześcijanin w Świecie” 1977, nr 59-60. 
Okólnik J. E. Biskupa Stanisława Adamskiego do zarządów, oddziałów i członków Akcji Katolickiej oraz Misji Wewnętrznej diec. katowickiej i Śląska Zaolziańskiego, Katowice 1939.

PeretiatKowicz A., Wiadomości prawno-polityczne, w: Polska współczesna. Geografia polityczna Polski. Kultura duchowa. Wiadomości prawno-polityczne, red. J. Bystroń, S. Pawłowski, A. Peretitkowicz, Lwów-Warszawa 1936.

Pierwsze sprawozdanie Związku Spółek Śląskich za rok 1914. Zestawił i ogłosił Ks. St. Adamski Przewodniczący Związku, Nakł. Związku Spółek Zarobkowych, Poznań 1915.

PRZYBYLSKI H., Chrześcijańska Demokracja i Narodowa Partia Robotnicza w latach 1926-1937, Wydawnictwo PWN, Warszawa 1980.

RZEPECKA Z., W służbie dobra i prawdy, Nakładem Zjednoczenia Młodzieży Polskiej, Poznań 1931.

Sprawozdanie Stenograficzne z 45 posiedzenia Sejmu Ustawodawczego z dnia 4 czerwca 1919. Sprawozdanie Stenograficzne z 55 posiedzenia Sejmu Ustawodawczego z dnia 25 czerwca 1919.

Sprawozdanie Stenograficzne z 83 posiedzenia Sejmu Ustawodawczego z dnia 1 sierpnia 1919. SzARANIEC K., Ks. Stanisław Adamski. W kręgu społecznej działalności, cz. 1, Muzeum Śląskie, Katowice 1990

SzArANieC K., Ks. Stanisław Adamski. W Naczelnej Radzie Ludowej, cz. 2, Muzeum Śląskie, Katowice 1991

SZARANIEC K., Ks. Stanisław Adamski. W Sejmie i Senacie, cz. 3, Muzeum Śląskie, Katowice 1991.

ŚLIWIŃSKA-ZARZECKA M., Wychowanie społeczne i obywatelskie, odbitka z „Oświaty Polskiej” (Nr IV, V 1938 r.), Warszawa 1938.

WoŹNICA B., Z historii diecezji katowickiej, „Chrześcijanin w Świecie” 1977, nr 59-60.

WYSZYŃSKI S., Nad mogiłą Biskupa - Męża Stanu, „Chrześcijanin w Świecie” 1977, nr 59-60.

ZIELENIEWSKI L., Zagadnienie mniejszości narodowych w Konstytucji Rzeczypospolitej. Zarys historyczno-dogmatyczny, Warszawa 1935.

\section{AKTYWNOŚĆ BISKUPA STANISŁAWA ADAMSKIEGO W OKRESIE II RZECZYPOSPOLITEJ}

\section{S t r e s z c z e n i e}

Artykuł Działalność Biskupa Stanistawa Adamskiego w okresie II Rzeczypospolitej w sposób złożony przedstawia kształtowanie się koncepcji Biskupa Adamskiego po odzyskaniu przez Polskę Niepodległości. Złożona problematyka tego okresu w historii Polski skłoniła Autorów do zwrócenia szczególnej uwagi na tematykę państwa, prawa, nauki, roli Kościoła katolickiego oraz gospodarki w myśli Biskupa Stanisława Adamskiego, postaci z całą pewnością obdarzonej niezwykłymi talentami - kapłana, obywatela, społecznika, ekonomisty, senatora.

Słowa kluczowe: Kościół katolicki; II Rzeczpospolita; nauka; prawo; gospodarka; Akcja Katolicka; państwo. 